\title{
Devir-mulher e educação múltipla: cartografias clariceanas
}

\author{
Gilcilene Dias da Costa' (iD 0000-0002-7156-5610 \\ Fabíola de Fátima Igreja' (iD 0000-0001-8591-7499 \\ 'Universidade Federal do Pará, Programa de Pós-Graduação em Educação e Cultura, \\ Cametá, PA, Brasil.68400-000 - ppgeduc@ufpa.br
}

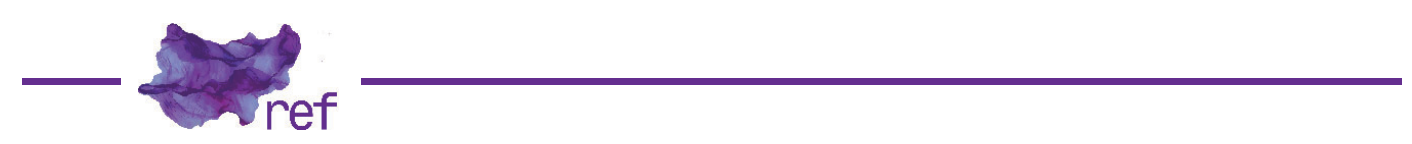

Resumo: O texto movimenta cartografias intensivas com a arte literária de Clarice Lispector ao encontro da construção de sentidos para uma educação múltipla. A partir dos percursos rizomáticos das mulheres clariceanas, visa romper com antigas representações que legitimam o 'ser mulher' segundo as leis do patriarcado. Estas veredas levam a maquinar o conceito de educação múltipla nos entremeios da filosofia da diferença, com Deleuze e Guattari, e das ressonâncias do pensamento pós-feminista, como Beauvoir e Butler, de modo a tecer as relações entre arte-gênero-educação por conexões rizomáticas e encontros intensivos com as potências feministas do devir-mulher, da escrita clariceana e os devires poético-políticos como possibilidade de fabular espaços de liberdade nas artes de viver e educar.

Palavras-chave: devir-mulher; arte menor; educação múltipla; Clarice Lispector.

\section{Becoming-Woman and Multiple Education: Clarice Cartographies}

Abstract: The text moves intensive with the literary art of Clarice Lispector to the encounter of sense construction for a multiple education. From the rhizomatic paths of Clarice's women, it aims to break with old representations that legitimize being a woman according to the laws of patriarchy. These paths lead to machining the concept of multiple education in the interweaving of the Philosophy of Difference, with Deleuze and Guattari, and the resonances of post-feminist thought, such as Beauvoir and Butler, in order to weave the relationships between art-gender-education through rhizomatic connections and intensive encounters with the feminist powers of becoming-woman, Clarician writing and the poeticpolitical becoming as a possibility of fabricating spaces of freedom in the arts of living and educating. Keywords: Becoming-woman; Poetic-political body; Multiple education; Clarice.

\section{Devenir-mujer y educación múltiple: cartografías clariceanas}

Resumen: El texto traslada cartografías intensivas con el arte literaria de Clarice Lispector al encuentro de construcción de significados para una educación múltiple. Partiendo de los caminos rizomáticos de la mujer claricia, pretende romper con antiguas representaciones que legitiman el "ser mujer" según las leyes del patriarcado. Estos caminos conducen a maquinar el concepto de educación múltiple en medio de la Filosofía de la diferencia, con Deleuze y Guattari, y de las resonancias del pensamiento posfeminista, como los de Beauvoir y Butler, para tejer las relaciones entre el arte. -educación de género a través de conexiones rizomáticas y encuentros intensivos con los poderes feministas del devenir-mujer, de la escritura clariciana y del devenir poético-político como posibilidad de fabular espacios de libertad en las artes de vivir y educar.

Palabras-clave: devenir- mujer; arte menor; educación múltiple; Clarice Lispector.

\section{Derivas iniciais}

A educação foi historicamente um direito interdito à mulher, que não podia ler, escrever e pensar para além dos limites que os sistemas de opressão, dentre os quais o patriarcal, impunham. Não obstante incontáveis séculos de interdição, as lutas coletivas caminharam e 
caminham para romper com as proibições física e intelectual aos espaços da educação, onde ter acesso aos conhecimentos socialmente produzidos vem configurando pautas feministas reclamadas por meio da luta por direito à liberdade e à educação. Mas admitimos que ainda lutamos contra a estagnação do tempo que joga como nosso oponente, embora também saibamos que muitas mulheres, no decurso das jornadas feministas, caminharam e caminham levando consigo um corpo coletivo de mulheres que lutam com suas bandeiras por direito à liberdade de viver e amar, direito à educação, à profissão, à vida digna, a desejos outros de transpor as barreiras impostas pela sociedade patriarcal.

Neste sentido, o trabalho perscruta o conceito de devir-mulher nos entremeios da literatura clariceana, a partir da ideia de uma educação múltipla, para tensionar, à luz de pensadoras feministas, as representações e estigmatizações do 'ser mulher' perpetradas pelo patriarcado, reforçadas no âmbito educacional, para propor contraposicionamentos e perspectivas de reterritorialização dos espaços do educar no encontro com a arte ao modo de um agenciamento político coletivo baseado em Gilles Deleuze e Félix Guattari (2003).

O desafio da aposta no devir-mulher de uma educação múltipla corrobora a percepção de que, embora as lutas feministas estejam conquistando espaços e debates em torno da condição da mulher e garantias de direitos na sociedade, não percebemos tais repercussões nas instituições de ensino, especialmente na educação básica, onde o atrelamento à transferência de conhecimentos se faz de modo meramente técnico e, bem ao contrário, estudos de gênero são deturpados, como se a educação fosse apenas um transferir de informação e conhecimentos. Nesse viés, a literatura na educação é comumente deixada em segundo plano, sendo colocada como suporte à transferência de informações ou apenas como entretenimento fortuito; lê-se para decodificar, para memorizar, para tecer uma breve discussão pautada em um funcionamento tecnicista de ensino em detrimento da potência poética e política da literatura.

A partir dessas preliminares, compõe-se uma rede transversal de conexões, zona de vizinhança (DELEUZE; GUATTARI, 2003), entre estas áreas para discutir o devir-mulher como potência poética e política da arte literária clariceana para pensar pulsações de uma educação múltipla. É pela cartografia das mulheres de Clarice, entre suas experiências e questões, que a pesquisa produz elementos à educação, não para dar um caminho ou um parâmetro de como trabalhar literatura ou gênero nas escolas, mas dar a pensar as relações e os modos de existência. Para tanto, há que se agenciar potências de conceitos que movam as engrenagens desta maquinaria-escritura em um atravessamento filosófico que perpassa o pensamento da diferença e os estudos feministas, bem como a abordagem filosófico-literária acerca da arte literária clariceana. Estas veredas nos levam a maquinar sentidos outros que movimentam conceitos no campo da educação.

Para pensar um devir-mulher na educação, a pesquisa ensaia fabulações de sentidos na literatura clariceana, traçando "uma linha feiticeira que foge ao sistema dominante" (DELEUZE; GUATTARI, 1997, p. 15) ou linhas que constituem trânsitos entre os escritos de Clarice para trazer uma arte menor provocadora e tensionadora das tramas sociais a partir de um olhar coletivo e, portanto, múltiplo à educação.

A educação escolar, em geral, é moldada a partir de uma forma definida que se ocupa primordialmente da função de informar, instruir, produzir subjetividades determinadas ao conservar valores a partir do padrão binário. É, em maioria, um lugar que preza pelo conhecimento que se dá pelo acúmulo de informações no qual o processo do educar fica reduzido. Mas há, nesses espaços, um ou outro movimento que burla esta regra social, propõe ir além da informação ou da finalidade, procura criar modos outros de pensar as relações, expandindo os espaços do educar dentro e fora da escola em um gesto inventivo, que compreende a potência formativa da educação e que também passa pela relação direta com as tramas sociais e as multiplicidades que nela se encontram e a atravessam. Por isso, a educação múltipla passa pelo devir, pois "devir não é atingir uma forma (identificação, imitação, mimese), mas encontrar a zona de vizinhança, de indiscernibilidade, ou de indiferenciação" (DELEUZE, 1997, p. 10).

Ao pensarmos a educação como devir, nós a vemos como espaço de circulação de corpos múltiplos, que estão em constante transformação a partir de seus afetos e encontros, consigo e com o outro, de existências diversas; e um educar múltiplo opera por forças minoritárias que se conectam à margem dos modos de existir constituídos como parâmetros sociais. A educação é um campo no qual podemos pensar e problematizar a normalidade das coisas, e é neste caminho que este texto quer se movimentar, a partir do devir-mulher na educação, questionando os modos de representações que subjugam corpos e feminilidades ao reforçar um padrão de existir que exclui e oprime. Devir-mulher não é, então, uma forma a ser atingida, tampouco uma condição restrita às mulheres, mas um movimento molecular que abarca todo um campo social, pelo qual se pode destituir a acepção convencionalista dos corpos e uma política patriarcal que determina um ser homem e um ser mulher.

O patriarcado oprime as singularidades e multiplicidades de cada mulher ao naturalizar as formas de existência por meio da regulação dos corpos desviantes, e a liberdade é ameaçada 
quando as possibilidades de as experimentar são cerceadas pela repressão falocentrista, pois, nesta política de opressão, há a violenta afirmação de uma universalidade que parte do padrão hierárquico no qual vidas valem mais que outras, no qual corpos passam a ser afirmados em detrimento de outros. Esse jogo invisibiliza existências, joga vidas à precariedade.

Ao falar das relações hierárquicas de poder que o sistema patriarcal institui, Margareth Rago (2004) provoca ao pensamento acerca da masculinidade produzida por tal sistema. Há, nas mãos das mulheres, ânsia e necessidade de luta por suas liberdades a partir dos seus atravessamentos interseccionais, mas é preciso também que o homem, na posição de privilégio nesta ordem patriarcalista, se faça traidor de uma supremacia masculina, hétero, cis, branca e colonial:

O pensamento feminista deve fundamentar suas análises críticas da natureza e das relações sociais no âmbito das vidas das mulheres. Entretanto, os homens também precisam aprender como fazer o mesmo a partir das suas condições históricas e sociais particulares, agindo como homens traidores da supremacia masculina e das relações de gênero convencionais (RAGO, 2004, p. 293).

Devir-mulher, neste sentido, passa pela ruptura de construções sociais ancoradas no patriarcado, que limitam a existência aos moldes de gênero e afirmam um ideal de mulher e de homem deslegitimando outros, passando também pelo ato de tensionar políticas que subjugam e encarceram o feminino em um padrão. Além disso, devir-mulher se dá ainda pela transgressão e destruição da concepção de um modelo de masculinidade enrijecido, traindo-o. Acerca do devir-mulher, escrevem Deleuze e Guattari (1997, p. 60):

É certamente indispensável que as mulheres levem a cabo uma política molar, em função de uma conquista que elas operam de seu próprio organismo, de sua própria história, de sua própria subjetividade: 'Nós, enquanto mulheres...' [...] capazes de percorrer e de impregnar todo um campo social, e de contaminar os homens, de tomá-los num devir. Partículas muito suaves, mas também duras e obstinadas, irredutíveis, indomáveis.

Quando Deleuze (1997) fala em tomar um campo social, possibilita-nos pensar o devirmulher como um acontecimento político que permeia toda uma sociedade. É crucial que questionemos o lugar determinado para nós, mulheres, na sociedade patriarcal, entendendo-nos não apenas como um corpo regulado por sistemas que impõem padrões quase intransponíveis de desigualdades de gênero, mas como um corpo político que tem por direito viver; no entanto, é preciso criar possibilidades para que este entendimento coletivo e político aconteça, pois cremos ser a educação, assim como a literatura, um caminho singular e importante para produzir tais possibilidades, sendo a literatura, então, enquanto arte minoritária, agenciamento coletivo para que mulheres tomem para si a potência de suas existências e de suas lutas.

\section{Arte menor}

A arte e a educação são alvos de sistemas hegemônicos que pretendem limitá-las às teias mercadológicas e de censura, posto que são capazes de minar a perversidade dos fantasmas da alienação e da opressão.

Ao tecer uma cartografia literária com os escritos de Clarice a partir do pensamento da diferença, desejamos produzir sentidos múltiplos à educação por meio desta arte menor. Na potência da força criadora da arte é possível transformar mundos, criar realidades, pois esta faz tensionar as estruturas de poder que enredam a educação. Além disso, podemos vivenciála por uma tal potência criadora como arte de educar, arte que não fique relegada a mero reforço de transferência de acúmulo do conhecimento, mas que seja também movimento, vida, invenção, arte como um canal de fabulações por meio do qual se liberam o pensar, o sentir, o viver. $E$, pensando nessa perspectiva, podemos estreitar esta arte menor com algumas categorias rizomáticas, do que se entende por literatura menor:

As três categorias da literatura menor são a desterritorialização da língua, a ligação do individual com o imediato político, o agenciamento colectivo de enunciação. $O$ mesmo será dizer que 'menor' já não qualifica certas literałuras, mas as condições revolucionárias de qualquer literatura no seio daquela a que se chama grande (ou estabelecida). (DELEUZE; GUATTARI, 2003, p. 41).

Arte menor não é então um gênero literário ou uma literatura específica, mas uma força coletiva, desterritorializante, que move a escrita e a torna minoritária. Desterritorializar, nesta acepção de Deleuze e Guattari (2003), é retirar a língua de um domínio majoritário, fazendo-a espaço de transgressão, uma língua que se move por devires, e devir é sempre minoritário, pois só se pode devir um 'povo que falta'. Assim também a arte menor nunca é uma arte do individual, pois se inscreve na coletividade; mesmo quando suscita lembranças e vivências da autora, a arte menor o faz por meio de um sentir-viver coletivo. 
Neste movimento a literatura torna-se múltipla, e aquela que escreve se despe das suas palavras, dando-as a ser movimento de leitores, destitui-se de um sujeito que fala e escreve para se tornar parte de vozes múltiplas, sabendo que "não há sujeito, só há agenciamentos coletivos de enunciação e a literatura exprime esses agenciamentos" (DELEUZE; GUATTARI, 2003, p. 41). Agenciar, neste sentido, é devir 'um povo que falta', deixar-se atravessar por um desejo minoritário a contrapor sistemas dominantes tal qual o patriarcado.

Destarte, a criação clariceana produz reterritorializações ao despertar quem a lê para um desconhecido de si, para um inquietar-se para além de um pensar autômato, por uma linguagem que faz olhar através do reflexo do espelho do qual falava a personagem de Água Viva (LISPECTOR, 1998a), este que não se limita na primeira imagem. A partir de uma arte menor, resvala pelas cascas culturais abrindo passagem para entrar no que a personagem clariceana chamou de "útero do mundo" (LISPECTOR, 1998a, p. XX), gruta de sentidos, de liberdades que ameaçam as convenções sociais excludentes. Neste sentido, uma arte menor é aquela pela qual podemos percorrer um caminho inverso, desviar das leis que instituem regulações; e uma literatura menor acontece nas tramas de uma linguagem plural, na língua maior que propõe tecer um corpo político coletivo. Neste sentido,

Uma literatura menor não pertence a uma língua menor, mas, antes, à língua que uma minoria constrói numa língua maior. E a primeira característica é que a língua, de qualquer modo, é afectada por um forte coeficiente de desterritorialização. (DELEUZE; GUATTARI, 2003, p. 38).

Ao falarmos em um ato de ruptura presente nas obras de Lispector, não se trata somente de uma questão estética das formas e normas do escrever, mas se refere sobretudo às relações de sentidos e olhares tramados na língua, visto que, ao romper um modo convencional e determinado de escrever, o faz a partir de inquietudes, pois quebra paradigmas não apenas da sintaxe, ao se desviar de uma estética de mundo naturalizada. Considerada por muitos como intimista, Lispector é definida por tecer viagens em particulares sensações; no entanto, sua escrita se engendra em críticas e desconstruções que eclodem de questões do existir cotidiano de suas personagens mulheres, lançando em torno da existência um olhar particular que perscruta os limiares da vida a partir de diversas questões.

Por assim dizer, a arte menor é também arte que propõe rupturas. Quando Lispector escreveu a respeito do ato de escrever, despojava-se do nome escritora, sentindo nele uma obrigatoriedade e uma formalidade que não diziam de sua relação com a arte, preferindo especular o termo amadora. Amadora pode ser aquela que escreve por amor, prazer, que faz pelo querer fazer, precisar dizer, sentir por meio daquilo que ama, e que, mais do que isso, opera um gesto poético de viver no mundo como alguém que se desvia da norma. Ser uma amadora para manter sua liberdade. Ora, amadora é dito normativamente daquela que não é profissional, daquela que possui pouca técnica naquilo que pratica. Ao desterritorializar tal conceito Clarice permite-nos questionar os modos com os quais aprisionamos a palavra e a própria arte, deixando-nos perceber que sua arte é um modo de dar vida ao inteligível, de dar nascimento a realidades, de escapar de um contorno concreto de mundo. Ao ser uma amadora, cria um mundo ininteligível, como ela diz, no qual sua arte vem à tona por "um coração que por vezes percebe" (LISPECTOR, 2010, p. 40, grifos nossos), completando:

Literata também não sou porque não tornei o fato de escrever livros 'uma profissão', nem uma 'carreira'. Escrevi-os só quando espontaneamente me vieram, e só quando eu realmente quis. Sou uma amadora? O que sou então? Sou uma pessoa que tem um coração que por vezes percebe, sou uma pessoa que pretendeu pôr em palavra um mundo ininteligível e um mundo impalpável. Sobretudo uma pessoa cujo coração bate de alegria levíssima quando consegue em uma frase dizer alguma coisa sobre a vida humana ou animal.

A ideia de amadora funciona como um desvio aos aprisionamentos que regulam o ser escritora. Sendo uma escritora amadora, Clarice reivindica sua autonomia e liberdade de escrever e de gritar por sua linguagem e inquietudes, que, em sua poética original, desvelam as relações de poder, de captura das subjetividades, bem como a captura da própria palavra, quando usada como forma de legitimar opressões e enquadramentos no âmbito existencial e literário. Na linguagem clariceana, seus escritos traçam entrelinhas, movimentando palavras, fertilizando-as de um silêncio que estilhaça e desnuda mundos. São derivas que se abrem ao desconhecido da arte a partir deste olhar amador.

Este é o modo como a escrita de Clarice se faz travessia entre as camadas conceituais, escrevendo na tentativa de descortinar, "escrevo-te porque não me entendo" (LISPECTOR, 1998a, p. 26), perguntar para não se agarrar ao primeiro movimento de tranquilo entendimento, fabular ao destituir-se de ser para se insurgir contra o que foi imposto, escrever para desobedecer às formas, às normas, seguir instintos que se proliferam a criar possibilidades de vazios plenos.

A arte é tal movimento que transgride o socialmente determinado, e as mulheres fabuladas por Lispector fundam uma realidade a partir da qual se faz possível viver em processo, pensar a 
mulher como um termo em processo (Judith BUTLER, 2017), e isso implica desconstruir a imagem representativa sem necessariamente substituí-la. Essas personagens mulheres nascem por uma escrita rizomática que engendra tramas e inquietudes, convida a povoar outros territórios do pensar.

A partir desta cartografia literária em Clarice imergimos em sua arte para produzir sentidos de uma educação múltipla, reafirmando o direito ao grito como nosso esforço poético e político para tensionar as linguagens majoritárias na educação. Falamos de um corpo político inscrito na linguagem clariceana capaz de tensionar a educação que se pauta nas normas patriarcais. Na língua estrangeira da arte de Clarice se inaugura um desvio da língua maior para questionar parâmetros socialmente instituídos, para delinear sentidos de uma educação múltipla, para movimentar os devires dessa arte menor em seus rios de criação.

\title{
Espantos
}

Em Um sopro de vida, Clarice (LISPECTOR, 1999) escreve a respeito de sua tela Caos, metamorfose e sem sentido. Três palavras que movimentam a experiência da personagem cartografada neste texto. Na abstrata imagem pintada sobre madeira, dançam as cores suspensas na tela, e o texto de Um sopro de vida conta a relação entre coisas que não se dizem respeito: a borboleta, nascendo por uma metamorfose, transformando-se, tornando-se, e a máquina de costura que transmuta tecidos em qualquer coisa que se possa pensar. Na máquina de escrever nasce essa transmutação que a autora jorra em suas telas. Tessituras de um corpo livre da arte, de uma imersão que se desmonta das normalidades da representação, permitindo-se escapar de uma imagem que facilmente pode ser distinguida, decifrada, que congela em si. A arte feita em imagens que se conectam e experimentam é uma arte do espanto que leva à deriva as certezas.

Em Amor, conto de Clarice Lispector (1998b), as descobertas e espantos de Ana nos conduzem aos espantos nascidos da arte menor, do mergulho no silêncio-encontro com a palavra poética. Esses encontros fazem despertar questões, assim como o cotidiano desperta na personagem um delírio desconhecido que a inquieta. Tensionando conceitos como felicidade e amor, a autora abre veredas de um percurso desconhecido pelo qual saímos da ideia determinada para aprender com Ana a espantar-se com essas palavras, pois, na descoberta de si, descobre também que tanto o sentido de amor quanto 0 de felicidade poderiam ser diferentes do que sempre lhe foi ensinado.

Tudo acontece quando "um pouco cansada, com as compras deformando o novo saco de tricô, Ana subiu no bonde." (LISPECTOR, 1998b, p. 12). A entrada no bonde antecede uma metamorfose que dá sentido ao caos que o silêncio do lar criara em seus pensamentos. "Depositou o volume no colo e o bonde começou a andar. Recostou-se então no banco procurando conforto, num suspiro de meia satisfação." (LISPECTOR, 1998b, p. 12). A procura que tece a obra clariceana envolve a personagem de Amor e dá início à transfiguração de sua relação com o mundo e consigo mesma ao ver uma cena imersa no cotidiano, a de um cego mascando chicletes: "O que havia mais que fizesse Ana se aprumar em desconfiança? Alguma coisa intranquila estava sucedendo. Então ela viu: o cego mascava chicles... Um homem cego mascava chicles." (LISPECTOR, 1998b, p. 13). Além disso,

\begin{abstract}
Ana ainda teve tempo de pensar por um segundo que os irmãos viriam jantar. O coração batiaIhe violento, espaçado. Inclinada, olhava o cego profundamente, como se olha o que não nos vê. Ele mastigava goma na escuridão. Sem sofrimento, com os olhos abertos. O movimento da mastigação fazia-o parecer sorrir e de repente deixar de sorrir, sorrir e deixar de sorrir como se ele a tivesse insultado, Ana olhava-o. E quem a visse teria a impressão de uma mulher com ódio. Mas continuava a olhá-lo, cada vez mais inclinada, o bonde deu uma arrancada súbita jogando-a desprevenida para trás, o pesado saco de tricô despencou-se do colo, ruiu no chão. Ana deu um grito, o condutor deu ordem de parada antes de saber do que se tratava o bonde estacou, os passageiros olharam assustados. (LISPECTOR, 1998b, p. 13).
\end{abstract}

Pelas divagações e inquietudes de Ana, Clarice critica, de forma irônica e sensível, representações identitárias maquinadas no feminino e ironiza o sentido de felicidade tramado para a personagem, em uma pretensa perfeição à qual a mulher é condicionada. Ana estava, pois, cumprindo um destino, vivendo uma realidade 'verdadeira' fruto da naturalização das representações socialmente forjadas:

No fundo, Ana sempre tivera necessidade de sentir a raiz firme das coisas. E isso um lar perplexamente the dera. Por caminhos tortos, viera a cair num destino de mulher, com a surpresa de nele caber como se o tivesse inventado. $O$ homem com quem casara era um homem verdadeiro, os filhos que tivera eram filhos verdadeiros. (LISPECTOR, 1998b, p. 12).

Ana vivera um destino inventado, forçosamente foi se ajustando para caber tanto a ponto de acreditar que ela mesma o havia tecido, ainda que lembrasse vagamente a menina viva 
em sonhos de anos escolares; tudo ficara para trás, sua vida resumia-se a cuidar dos filhos e do marido, sua existência ganhava sentido em dedicar-se à vida destes que dela dependiam. Lispector escreve os abandonos, sonhos, expectativas e possibilidades que são deixadas para trás por uma vida outra que soterra em lembranças distantes a felicidade do que, para as mulheres, eram e ainda são, em muitos sentidos, clandestinidades:

Sua juventude anterior parecia-lhe estranha como uma doença de vida. Dela havia aos poucos emergido para descobrir que também sem a felicidade se vivia: abolindo-a, encontrara uma legião de pessoas, antes invisíveis, que viviam como quem trabalha - com persistência, continuidade, alegria. O que sucedera a Ana antes de ter o lar estava para sempre fora de seu alcance: uma exaltação perturbada que tantas vezes se confundira com felicidade insuportável. Criara em troca algo enfim compreensível, uma vida de adulto. Assim ela o quisera e escolhera. (LISPECTOR, 1998b, p. 12-13).

Entretanto a personagem não vive confortavelmente. E Clarice aponta, em fragmento outro, certo esforço de Ana para sentir-se feliz, confundindo sensações, negando algo que nela pulsa sempre que o vazio do lar a engole, quando os seus saem para a vida. O espanto tomava conta de Ana nesses momentos de silêncio e solitude, por isso pondera um retorno aos pensamentos de adolescência e os expulsa com a certeza de que tudo que viveu estará para sempre interditado, atribuindo à imensa felicidade de vida adulta a sua 'exaltação'. Mas Ana não a escolhera, imersa em uma realidade traçada pelas determinações patriarcais "que justificam as desigualdades sociais entre homens e mulheres, remetendo-as, geralmente, às características biológicas" (Guacira LOURO, 1997, p. 24).

Nesta lógica, estar casada concedia confortabilidade, sobretudo na tranquilidade em cumprir um destino, o estereótipo de rainha do lar, estampado em tantas revistas e propagandas. Pensara Ana que a vida 'perfeita', em que poucas vezes se fazia protagonista, era a única coisa que poderia desejar. Ela afasta o espanto de si que fazia da vida um constante latejar, pois dar espaço ao silenciar da casa que a trazia para si mesma poderia afastá-la da firme raiz patriarcal que a mantinha. No entanto, quando ninguém mais carecia de seus cuidados e ela podia se notar, retornava ao pensamento o tal espanto de si mesma:

Sua precaução reduzia-se a tomar cuidado na hora perigosa da tarde, quando a casa estava vazia sem precisar mais dela, o sol alto, cada membro da família distribuído nas suas funções. Olhando os móveis limpos, seu coração se apertava um pouco em espanto. Mas na sua vida não havia lugar para que sentisse ternura pelo seu espanto (LISPECTOR, 1998b, p. 13).

Tentar afastar o espanto de si pelo medo de fugir às normas sociais tornara-se inútil no fundo, Ana só podia encenar uma vida 'verdadeira', posto que não plantara suas sementes, as da jovem estudante, mas havia o espanto que trazia à tona uma Ana que cultivara um espanto de vida. Clarice abre possiblidades a problematizar esta maquinação que controla as vontades por meio de uma falsa liberdade de escolha que está atrelada à naturalização dos papéis políticos e sociais baseados no binarismo homem-mulher. Ana credita ter escolhido sua vida, ainda que a narradora entregue uma falsa felicidade, descobre que, sem liberdade de desejo e sonhos, viver se limita a cumprir determinações, um 'destino de mulher' classificando os modos de felicidade a partir de uma condição biológica. Nesta lógica a mulher só é feliz se atender aos modelos de existência designados pela sua condição a partir do gênero. Ana esforçava-se para naturalizar essa realidade como a única, ser à sombra de um útero que reproduz para procriar.

Neste sentido indagamos: como a educação poderá agir de modo a desconstruir tais estruturas patriarcais? Pois, se a imagem construída pelo patriarcado em relação à mulher ainda não foi apagada, para as mulheres, não há uma plena liberdade no viver, no pensar, no escolher, e, por isso, a educação se faz fundamental; porém, não qualquer educação, não qualquer educar, mas uma educação múltipla que atravesse e se prolifere no pensar e no ler, no aprenderensinar. Uma educação que impulsione a vida em seus atravessamentos, em seus espantos. Por isso a imagem do devir-mulher faz-se potente no ato de educar com a multiplicidade. Se não se combatem os modelos binários de existência, a educação acaba por legitimá-los.

Ana afasta de si o perigo de viver, porque a ela foi negado um viver nomeado como perigo a ser afastado por um meio social e por uma educação que não confronta tais normas, não permite que se corra os próprios riscos de existir. Então, o que é este perigo a ser apagado, negado e 'censurado' nos processos do educar?

Ana é um corpo regulado, um corpo moldado e jogado em sua prisão social que parece ser a confortável felicidade; não que ela não amasse os filhos e o marido, porém, poderia amarse livremente? Sem culpa? Deixando de atender as funções determinadas para seu gênero? Neste sentido, Butler, a partir de Foucault, comenta:

Foucault observa que os sistemas jurídicos de poder 'produzem' os sujeitos que subsequentemente passam a representar. As produções jurídicas de poder parecem regular a vida política em termos puramente negativos — isto é, por meio da limitação, proibição, regulação, controle e 
mesmo 'proteção' dos indivíduos relacionados àquela estrutura política, mediante uma ação contingente e retratável de escolha. Porém, em virtude de a elas estarem condicionados, os sujeitos regulados por tais estruturas são formados, definidos e reproduzidos de acordo com as exigências delas (BUTLER, 2017, p. 18-19, grifos da autora).

Ao relacionar ao conto de Clarice é possível dizer que, neste mecanismo, a ideia maquinada de escolha condiciona a resignação de Ana e que as instituições como família e escola operam por meio de uma conduta e um discurso estabelecido. Ana se sente protegida, ao passo em que acredita estar cumprindo a função que seu gênero naturalmente lhe impõe (definida como sinônimo de feminino ou feminilidade estereotipada). Esta representação limita e define e, por definir, exclui a multiplicidade produzindo tal imagem: mulher dona de casa, esposa, mãe, branca e heterossexual; e, no caso de Ana, os limites de uma vida privada, dedicada à família e aos afazeres da casa são seu 'destino de mulher'. Estas representações discursivas definem critérios que regulam os comportamentos e determinam a subjetividade a partir de estruturas jurídicas que tendem a moldar comportamentos.

Contrapondo as amarras de regulação de uma educação que opera a favor das normatividades, experimentamos os espantos de Ana por meio da potência de uma arte menor em sua força poética e política, que produz espantos para um educar múltiplo. Neste educar é possível sentir ternura pelo seu espanto, viver à deriva suas inquietações e insurgir-se a este destino de mulher e suas mais complexas formas de regulação; uma educação múltipla entre espantos e derivas, a vida rebentada ao romper as cordas do patriarcado que a regula.

Ao ver o cego mascando chicletes, Ana percebe que sua cegueira é que era nociva, porque estava cega de mundo, uma cegueira social construída por um sistema que a reprimia a ponto de resigná-la. A personagem desperta para a felicidade clandestina ao ver o cego entre o trepidar brusco que rompe a rede com a sacola de compra docilmente tecida por ela. Ana experimentou a ruptura de seus medos dando espaço para que os espantos emergissem no átimo em que tudo rompe a sacola, a casca do ovo, as certezas e seus medos. Ana desperta para as derivas que com veemência tivera ignorado. A metamorfose se inicia de repente, e a casca-casulo começa lentamente a se romper. Desnorteio. A mulher desce do bonde sem destino. Uma desconhecida. À deriva. É preciso tal desnorteio de si, afinal, 'perder-se também é caminho', quiçá o mais importante para reencontrar-se na liberdade de viver:

O mundo se tornara de novo um mal-estar. Vários anos ruíam, as gemas amarelas escorriam. Expulsa de seus próprios dias, parecia-lhe que as pessoas na rua eram periclitantes, que se mantinham por um mínimo equilíbrio à tona da escuridão - e por um momento a falta de sentido deixava-as tão livres que elas não sabiam para onde ir. (LISPECTOR, 1998b, p. 14).

Esta falta de sentido na qual Ana fora envolta é um elemento provocador da arte de Clarice, pela qual fabula a dimensão da procura pela liberdade de existir. Pois é curioso para Ana perceber-se tão livre no mundo, sentir que poderia existir além da sua reação com os outros, o marido, o filho, a experiência periclitante com o banal; provocou a prova de uma liberdade tão única que mal sabia o que fazer, o mundo era agora um mal-estar, talvez pela culpa engendrada em si, tendo estado a vida presa por representações sociais, talvez porque do mal-estar é possível mover-se, descobrir que se está nascendo da falta de sentido, deixando uma vida dentro destes anos que ruíam. Não saber para onde ir é como um se tornar pleno, como um devir-mulher, ou descobrir que:

a mulher em si é um termo em processo, um devir, um construir do qual não se pode dizer legitimamente que tenha origem ou fim. Como uma prática discursiva contínua, ela está aberta à intervenção e à ressignificação. Mesmo quando o gênero parece se cristalizar nas formas mais reificadas de a 'cristalização'. (BUTLER, 2008, p. 33 apud Sara SALIH, 2015, p. 60).

Ver o cego na rua despiu-Ihe a cegueira da vida e a fez desconhecer os dias em que estava, mas era a ela mesma que estava já desconhecendo. Assim como as borboletas e as máquinas de costura na tela Caos, metamorfose e sem sentido indicam a metamorfose do ser que rompe, corta e reterritorializa sua realidade e a si mesmo, a morte que Ana imaginara era renascimento para um amor vigoroso. A experiência fez renascer a jovem mulher cheia de sonhos e desejos que tentara expurgar de si. Ela se entregou à crueza tranquila de si. Esta morte de uma Ana subserviente era a transfiguração, a metamorfose que aos poucos substituía a repulsa que ainda sentia desta espécie de libertação, dando lugar ao fascínio e ao prazer de uma liberdade primitiva do corpo.

Esta imagem que provoca a experiência de Ana rompe com a ideia de um mundo já determinado para a personagem e, mais especificamente, nas relações pautadas em binarismos hierarquizados: o homem, o provedor com livre acesso aos espaços públicos e sociais, e a mulher, a subserviente que doa a vida em prol dos filhos e do marido e aos cuidados do lar. A imagem de Ana em seus espantos nos lança a pensar em relação à imagem representativa da 
mulher; criada e legitimada pelo patriarcado, foge à permanência dos padrões para tornar-se um corpo em processo, em devir:

Ninguém nasce mulher: torna-se mulher. Nenhum destino biológico, psíquico, econômico define a forma que a fêmea humana assume no seio da sociedade; é o conjunto da civilização que elabora esse produto intermediário entre o macho e o castrado que qualificam de feminino (Simone de BEAUVOIR, 1967, p. 09).

Nenhum destino deve determinar ou definir, mas as estruturas sociais insistem em tornar a mulher um 'segundo sexo'. Em Ana vemos que sua experiência rompe com essa determinação de 'macho castrado' imposto ao corpo e à liberdade da mulher, redimensionando o 'tornar-se' enquanto mecanismo de opressão dos corpos delimitados para um 'tornar-se' em movimento de devir, em constante metamorfose. Envolta em um mundo de liberdade delirante, Ana não mais reconhece sua casa, como um retorno ao que soara distante, desconhece seu filho, seus dias. Retoma a vida cotidiana, ocupa-se em preparar o jantar em família, mas, depois da reunião, quando todos recolhidos, "ela era uma mulher bruta que olhava pela janela" (LISPECTOR, 1998b, p. 19) e que, ponderando entre os mundos, indaga: "O que o cego desencadeara caberia nos seus dias? Quantos anos levaria até envelhecer de novo?" (LISPECTOR, 1998b, p. 19); mas a sensação de culpa e medo a faz ponderar: "Qualquer movimento seu e pisaria numa das crianças" (LISPECTOR, 1998b, p. 19). Um barulho lá fora, de dentro da realidade, a desperta; era o barulho do fogão no ambiente em que o marido estava. Lispector tece a cena na qual o amor pelo marido carrega Ana para a interdição, ele a envolve e:

Ela continuou sem força nos seus braços. Hoje de tarde alguma coisa tranquila se rebentara, e na casa toda havia um tom humorístico, triste. É hora de dormir, disse ele, é tarde. Num gesto que não era seu, mas que pareceu natural, segurou a mão da mulher, levando-a consigo sem Olhar para trás, afastando-a do perigo de viver. (LISPECTOR, 1998b, p. 19).

Afastar a mulher do perigo de viver é sempre algo que justifica o seu aprisionamento em mundos e valores patriarcais que insistem em conformá-la ao modelo instituído do ser mulher. Nesta cena Clarice expõe o poder de interdição disfarçado de cuidados do homem em relação à mulher. Na sutileza do carinho o marido de Ana a desvia da novidade de tudo o que não concerne ao ambiente a ela permitido. Olhando-se no espelho, resta o contentamento em preparar-se para o dia seguinte, quando os móveis a solicitarão, quando tudo o que não a fará delirar de amor por si estará à sua espera, e "antes de se deitar, como se apagasse uma vela, soprou a pequena flama do dia" (LISPECTOR, 1998b, p. 19). O mal-estar de Ana aconteceu na ruptura com o que controlava seu sentimento, suas escolhas, seus passos. Ela se perdeu pelo caminho e entrou no mais íntimo de si, ao desconhecer-se, permitiu-se estar à deriva.

Na educação, é possível abraçar aquilo que pode ser um mal-estar, um à margem do socialmente confortável, e possibilitar às mulheres a liberdade de abraçar seus perigos e suas sensações insurretas, que podem vir como um mal-estar para uma sociedade forjada por homens? Neste sentido, é necessário, no ato de educar, produzir questionamentos e espantos para produzir espaços de multiplicidade nos quais a arte com seus espantos seja a potência para experimentar as derivas de si, como Ana experimentou. A arte em sua força poética pode produzir rupturas, fissurar as armadilhas do patriarcado e levar as mulheres ao encontro das coletividades, abrindo caminhos de lutas por novos sentidos de existir.

\section{Convulsionar da palavra}

Nos labirintos dos escritos de Clarice contestamos a designação patriarcal que relegou ao feminino o símbolo de repressão do corpo, uma sexualidade regulada a serviço da procriação. Sobre o órgão vigilante ao destino da mulher, Veronica Stigger (2016, p. 07) lembra que "na Grécia antiga, o útero era descrito como um animal vivo que se deslocava pelo corpo feminino"; nesta concepção, a animalidade, designada como força opressora, determina um destino biológico pela imagem do útero que se move no corpo da mulher, debatendose, avisando a obrigatoriedade da procriação, determinada como função ou destino natural das mulheres. A imagem de um ideal de mulher que se confunde com ser mãe compõe uma série de comportamentos construídos para a mulher, como a docilidade e a subserviência aos desígnios de sua própria sexualidade.

Estas determinações ao corpo das mulheres são, desde há muito, mecanismos discursivos utilizados para reforçar uma representação opressora que opera pelo controle do agir, do sentir e do prazer, reforçando formas de regulação que põem os devires do corpo contra si. Um útero era então representado como animal que controla, que reprime, que produz histerias. "Talvez venha daí a crença corrente de que as mulheres eram mais propensas a não refrear seus impulsos, a não ter total controle sobre suas ações" (STIGGER, 2016, p. 07), tendo que ser controladas e redimensionadas aos seus destinos. A partir da gruta de Clarice, tramamos a criação de um corpo-educação que experimenta convulsões e devires. No movimento de 
entrar na gruta de Clarice, produzimos um encontro com suas sensações íntimas, seus medos, seus desejos, suas angústias e suas liberdades, que passam a ser também os nossos.

Neste sentido, a intenção é tramar uma reversão da animalidade situada como repressão às capacidades e experiências, colocando-a como metáfora de um corpo livre que se rebela às maquinações morais, e desviar da construção moralizante que põe a diferença como um horror normalizado, propondo fabular um corpo que convulsiona liberdades pela devoração, encontro com o outro, ao mesmo tempo em que se denuncia a imagem de uma determinação do corpo pela maquinação de parâmetros biológicos.

Desejamos pensar de que modo, por meio da reversão de uma animalidade situada como repressão às capacidades e experiências da mulher, podemos fabular um corpo que convulsiona expelindo de si as amarras sociais. Na gruta se movem devires de indiscernibilidade, um corpo que se transubstancia pela entrega ao primitivo, à negação do padrão binário como parâmetro da existência. Lispector permite falar de um corpo que se confronta, se desmonta, um corpo que, não passando apenas pelo corpóreo (físico), acontece então pelo entremeio da singularidade e da coletividade. A partir destes conflitos se abre um corpo-rizoma da educação, que, ao devir-imperceptível, desmonta em si o julgo patriarcal; um corpo convulsivo da educação, pois:

O corpo convulsivo, indomável, é também, portanto, um corpo livre de qualquer predeterminação biológica absoluta, um corpo que se destrói, se deforma, no sentido de que perde sua forma original e, ao se destruir e se deformar, se transforma, ou melhor, se fabrica novamente. (STIGGER, 2016, p. 10).

A linguagem é o lugar pelo qual se constituem as opressões, as verdades, os discursos reguladores (BUTLER, 2017) que fabricam as representações de ser mulher, mas também as identidades fixas que negligenciam a multiplicidade. No entanto, a linguagem não é uma ferramenta, mas a constituição das relações de poder que operam discursos opressores, mas também dos sentidos múltiplos, das fabulações. É pela linguagem que esse corpo convulsiona, ou é por este convulsionar da linguagem (LISPECTOR, 1998a) que se insurgem os discursos dominantes.

Em Água Viva, esta ruptura acontece por "uma língua tensa" (LISPECTOR, 1998a, p. XX), uma língua que tensiona a fixidez das coisas, do humano e da própria linguagem. Pelo delírio desejoso, sensações em indiscernibilidade, a animalidade é fabulação da intertroca (Evando NASCIMENTO, 2012). A linguagem de Água Viva (LISPECTOR, 1998a) produz vizinhanças ao pensamento da multiplicidade pelos signos artísticos que Lispector nos dá a ler. Estes signos nos levam a tecer sentidos de um corpo convulsivo da arte, da linguagem e da educação.

$\mathrm{Na}$ imagem da gruta fabulamos um devir-animal que desloca o humano dotado de convencionalismo e de suas bases dualistas, (homem-mulher, humano-animal, verdadeirofalso). Nesta feita, as imagens da escrita de Clarice convulsionam a percepção da animalidade como opressão do corpo feminino, trazendo ao cerne não mais o útero como um animal que determina o destino, mas o útero-gruta a ser experimentado. Na arte, a linguagem é esta gruta a ser sentida e vivida pela singularidade do corpo, pois acontece por meio da criação; nela podemos fabular devires de um corpo que se recoloca: perder-se de si para devir a si, destituir-se de um eu mulher para devir-mulher. Em Clarice isto se dá também pela ruptura com o convencionalismo tanto da linguagem quanto do modo como adentra os seus temas, destituindo também as convencionalidades discursivas. Sua arte, como signo da fabulação, é potência, que por meio da linguagem insurge à própria linguagem.

Clarice, por sua escrita, impulsiona-nos a percorrer a gruta que gesta devires em uma arte que convulsiona. Um corpo que se destitui de uma forma normativa é um corpo em devir. Em $A$ paixão segundo G.H. (LISPECTOR, 2009), a potência de um corpo que se desconfigura é latente na imagem da barata partida e provada pela narradora, romper de um corpo que opera em G.H. um rompimento incorpóreo e põe em comunhão com o grotesco corpo dilacerado da barata, potencializado à medida que a mulher se despersonaliza de um eu convencional, "caminho em direção à destruição do que construí, caminho para a Despersonalização" (LISPECTOR, 2009, p. 117).

Tudo que G.H. sabia sobre si eram discursos forjados pelo convencional. Mas, ao "fabricarse novamente" (STIGGER, 2016, p. XX), abraça o horror da vida, vida em estado de horror, e, "aquele horror, isso era amor?" (LISPECTOR, 2009, p. 11). A arte de Clarice delira então todo um sistema de leis do existir, uma loucura inventiva que salva, pois "a loucura inventiva é uma dádiva, liberada pela força de um ilimitado amor, que só o não humano é capaz de suscitar" (NASCIMENTO, 2012, p. 104).

G.H. pensava ser mais um dos dias corriqueiros, franzido apenas pela tarefa de limpar o quarto antes usado pela mulher que trabalhou em sua casa. Antes de entrar, despojou-se da fumaça furtivamente inalada, enquanto olhara os arredores que se expandiam e eram já a reverberação de mundo nos seus longínquos pensamentos. Mas é ao entrar no quarto, armadilha de uma gruta de horrores, que a narradora prova da destruição de suas certezas, 
"essa destruição de camadas e camadas arqueológicas humanas" (LISPECTOR, 2009, p. 48). Neste atravessar, um corpo convulsivo aflora entre o eminente horror da barata esmagada causando a perda de uma identidade fixa e conceitual, e "perder os invólucros de lagosta faz frio" (LISPECTOR, 2009, p.79), causa horror-estranhamento de um desconhecido, mas perder a dura carapaça que sustentava uma identidade tramada em convenções sociais é também experimentar um fluxo de sensações delirantes, metamorfoses, "metamorfose em processo" (STIGGER, 2016, p. 09) que com G.H. foi:

Ontem de manhã quando saí da sala para o quarto da empregada - nada me fazia supor que eu estava a um passo da descoberta de um império. A um passo de mim. Minha luta mais primária pela vida mais primária ia-se abrir com a tranquila ferocidade devoradora dos animais do deserto. Eu ia me defrontar em mim com um grau de vida tão primeiro que estava próximo do inanimado. (LISPECTOR, 2009, p. 14).

Em A paixão segundo G.H. (LISPECTOR, 2009) a intertroca acontece no ato de defrontar-se com tal grau primeiro de si, como a exemplo de Água Viva (LISPECTOR, 1998a), "a radicalidade dessa experiência está no estranhamento de si que acontece de maneira não calculada" (NASCIMENTO, 2012, p. 32). O que se dá pela despersonalização, "a despersonalização como a destituição do individual inútil" (LISPECTOR, 2009, p. 118). Quando experimenta o encontro com a barata, o que prova é a desorganização do humano convencionado, que implica questionar toda uma construção social da qual a ideia de humanidade está solidificada; assim, a perda de 'uma vida organizada' a carrega por um retorno à vida primária, estranhando tudo o que julgara ser a constituição de sua condição de humana. G.H. prova um 'estranho' que vem à tona ao provar a barata, mas assim como a personagem sem nome de Água Viva, "quando estranho a vida aí é que a vida começa" (LISPECTOR, 1998a, p. 76). No deslocamento de suas certezas pelo encontro com um corpo, biológico (a barata) e social (identidade), a mulher é apresentada à vida em metamorfose:

O horror será a minha responsabilidade até que se complete a metamorfose e que o horror se transforme em claridade. Não a claridade que nasce de um desejo de beleza e moralismo, como antes mesmo sem saber eu me propunha; mas a claridade natural do que existe, e é essa claridade natural o que me aterroriza (LISPECTOR, 2009, p. 10).

Se pensarmos a experiência de G.H. no âmbito da educação, podemos questionar: o que nela se transforma? Que espantos se fabulam na educação para que ela se metamorfoseie em um corpo que se convulsiona contra o patriarcado? E, aqui, convulsionar passa pelo movimento de inquietude, de recusa; recusar o convencional como parâmetro, as leis patriarcais como ordem de viver, recusar o feminino como alvo de controle. Por esta recusa ansiamos uma educação que convulsiona, expelindo o que não nos cabe mais, expelindo um corpo que nada faz gestar, que nada produz de criativo. Expelir um educar que não se despersonaliza de si, pois paralisa-se na ideia de um animal que controla corpos, determinando finalidades segundo a moral patriarcal.

O horror da moral são os corpos não normativos. Tudo que é posto como abjeção social é colocado como escória dos bons costumes. Uma mulher que foge ao padrão de feminilidade é colocada sob o estigma de estranha, assim como um homem que destoa do padrão heteronormativo. $O$ estranho serve de eufemismo (maquiagem que forja a intencionalidade dos discursos excludentes) para a ideia subjugadora que aponta a afirmação de um padrão único. Estranho é um corpo que se apresenta como livre, solto, deformado aos olhos do padrão (patriarcal de beleza e de corpo). Um corpo estranho é um corpo horrendo, ameaçador. Em G.H., o estranho e o horrendo são movimentos de saída de si na intertroca, em experimentar o que vem do outro, esse outro não limitado ao humano, como a barata em G. H. e a gruta, as flores e os objetos em Água Viva (LISPECTOR, 1998a). A questão colocada é: como a educação se relaciona com este 'doce horror' do qual ela é constituída? Acolhendo-os ou agindo feito animal feroz que controla seus corpos, segundo a designação grega que Stigger (2016) mencionou?

Para que o horror seja um processo metamórfico, espaço de possibilidade da intertroca, é preciso abrir-se para ele, e a maneira que podemos encontrar é justamente a desterritorialização, a saída de um corpo conceitual que se afirma pela identidade constante e solidamente constituída da educação que forma para o certo, para a ordem, para as conquistas profissionais. Então um corpo que não se questiona ou convulsiona, seja este um corpo educacional, não pode metamorfosear-se em corpo coletivo e político. O corpo da educação viva devém um corpo políitico. Experimentar uma intertroca pelo olhar aberto ao 'doce horror' constitui um gesto político.

Experimentar adentrar em nossas grutas não para encontrar a verdade do mundo, mas para rompê-las quando oprimem e violam outras existências é assim também o movimento múltiplo de educar, afetar o outro com um trocar de sentidos, de linguagens, no qual os utilitarismos não instaurem hierarquias que pautem o educar. Assim fabulamos um corpo 
político do educar neste espanto da arte, que desperta para a multiplicidade da vida, que em seus silêncios provoca ruminações e encontros, um território do pensar, do sentir que nos dá possibilidade de tramar uma educação rizomática, pois "o rizoma é sempre um rascunho, um devir, uma cartografia a ser traçada sempre e novamente" (Silvio GALLO, 2003, p. 95). Cumpre então pensar uma educação por esta gruta que se está por descobrir e que dá espaço ao devir, que não se rende a um parâmetro normativo, pensar uma educação múltipla por um devirmulher que não se encerra em um conjunto de convenções. A multiplicidade, sufocada pelas duras carapaças sociais, pode emergir da arte menor que rebenta no estilhaçar do silêncio, experiência radical da despersonalização que o dizer não alcança, espantos de vida que a arte faz nascer.

\section{Derivas finais}

Nos interstícios da literatura propusemos apresentar inquietudes e indeterminações que atravessam as mulheres de Clarice para lançar discussão em torno das imagens representativas produzidas pelo discurso patriarcal. Além disso, propusemos problematizar a partir da arte literária de Clarice, entre uma linguagem singular e por um movimento descontínuo, uma arte menor que produz transmutações, espantos, multiplicidades de devir-mulher nos processos do educar. É neste sentido que experimentamos pensar uma educação múltipla, por uma língua menor da arte-escritura clariceana que reverbera possibilidades de nascimento nas artes do educar. Educar não apenas para as funcionalidades, para a apropriação de saberes, mas para a transmutação do existir, do nascer politicamente para si e para outras, povoando as relações por um atravessar coletivo de multiplicidades.

Nesta escrita de fronteira entre derivas experimentamos a potência de uma educação múltipla, que se convulsiona a expelir as normalidades inscritas em seu corpo. Pela transvaloração e potência do corpo estranho questionamos as imagens moralizantes e opressoras que constituem as tramas sociais e, por conseguinte, a educação, fabulando a criação de uma educação convulsiva neste gesto de enfrentamento ao patriarcado. Neste reterritório do corpo feminino, uma linha de fuga ao convencional, suscitamos pensar uma educação que devore a potência do outro, convulsionando a linguagem normativa do existir, fazendo bombear em suas veias um corpo político coletivo, corpos relegados que a educação, ao devorar, comunga e experimenta pela sua transfiguração.

Assim, as cartografias literárias do corpo político da arte-literatura clariceana reverberam desafios e potências ao direito ao grito que emana das multiplicidades de existires coletivos ecos vindos da gruta-pensamento, útero do mundo que abriga um doce horror e um terrível desejo, uma afecção que se quer atravessamento e contágio, arte menor como processo de fabular uma educação múltipla, ressoando travessias que abrem passagem, assim como nestas páginas se abrem novos devires na arte-literatura de Clarice.

\section{Referências}

BEAUVOIR, Simone de. O segundo sexo: a experiência vivida. São Paulo: Difusão europeia do livro, 1967.

BUTLER, Judith. Problemas de Gênero: feminismo e subversão da identidade. 15. ed. Rio de Janeiro: Civilização Brasileira, 2017.

DELEUZE, Gilles. Crítica e clínica. São Paulo: Ed. 34, 1997.

DELEUZE, Gilles; GUATTARI, Félix. Mil Platôs: capitalismo e esquizofrenia, v. 4. Rio de Janeiro: Ed. 34, 1997.

DELEUZE, Gilles; GUATTARI, Félix. Kafka: por uma literatura menor. São Paulo: Assírio e Alvim, 2003.

GALLO, Silvio. Deleuze \& a Educação. Belo Horizonte: Autêntica, 2003.

LISPECTOR, Clarice. Água Viva. Rio de Janeiro: Rocco, 1998a.

LISPECTOR, Clarice. A paixão segundo G.H. . Rio de Janeiro: Rocco, 2009.

LISPECTOR, Clarice. Crônicas para jovens: de escrita e de vida. Rio de Janeiro: Rocco Jovens Leitores, 2010.

LISPECTOR, Clarice. Laços de Família. Rio de Janeiro: Rocco, 1998b.

LISPECTOR, Clarice. Um sopro de vida. Rio de Janeiro: Rocco, 1999. 
LOURO, Guacira Lopes. Gênero, sexualidade e educação: uma perspectiva pós-estruturalista. Petrópolis: Vozes, 1997.

NASCIMENTO, Evando. Clarice Lispector: uma literatura pensante. Rio de Janeiro: Civilização Brasileira, 2012.

RAGO, Margareth. "'mulher cordial': feminismo e subjetividade". Verve: revista semestral autogestionária do Nu-sol, São Paulo, n. 6, p. 279-296, fev. 2004.

SALIH, Sara. Judith Butler e a teoria Queer. Belo Horizonte: Autêntica, 2015.

STIGGER, Veronica. O útero do mundo. São Paulo: Man, 2016.

Gilcilene Dias da Costa (costagilcilene@gmail.com) é professora da Universidade Federal do Pará (UFPA). Doutora e Mestra em Educação pela Universidade Federal do Rio Grande do Sul (PPGEDU/UFRGS). Coordenadora do PPG em Educação e Cultura (PPGEDUC/UFPA). Docente do PPG de Doutorado em Educação da Amazônia (PGEDA). Pesquisadora nas áreas de filosofia da diferença, cartografias literárias, devir-mulher, estudos queer, feministas, gênero, sexualidade, antropofagia e educação.

Fabíola de Fátima Igreja (gusmaofabi@gmail.com) é mestra em Educação e Cultura pelo Programa de Pós-Graduação em Educação e Cultura (PPGEDUC-UFPA) na qualidade de Bolsista CAPES. Licenciada em Letras - Habilitação em Língua Portuguesa (CUNTINS/UFPA). Membro do grupo de pesquisa ANARKHOS - Micropolíticas, Arte-Performance e Experimentações Literárias na Educação (CNPq/UFPA). Membro do Coletivo de Mulheres Sumanas (CUNTINS/UFPA). 
COMO CITAR ESTE ARTIGO DE ACORDO COM AS NORMAS DA REVISTA

COSTA, Gilcilene Dias da; IGREJA, Fabíola de Fátima. "Devir-mulher e educação múltipla: cartografias clariceanas". Revista Estudos Feministas, Florianópolis, v. 29, n. 3, e71499, 2021.

\section{CONTRIBUIÇÃO DE AUTORIA}

Gilcilene Dias da Costa: Elaboração, escrita e revisão conjunta.

Fabíola de Fátima Igreja: Elaboração, escrita e revisão conjunta.

\section{FINANCIAMENTO}

Este trabalho foi realizado com apoio da Coordenação de Aperfeiçoamento de Pessoal de Nível SuperiorBrasil (CAPES) - Código de financiamento 001.

\section{CONSENTIMENTO DE USO DE IMAGEM}

Não se aplica.

\section{APROVAÇĀO DE COMITÊ DE ÉTICA EM PESQUISA}

Não se aplica.

\section{CONFLITO DE INTERESSES}

Não se aplica.

\section{LICENÇA DE USO}

Este artigo está licenciado sob a Licença Creative Commons CC-BY 4.0 International. Com essa licença você pode compartilhar, adaptar, criar para qualquer fim, desde que atribua a autoria da obra.

\section{HISTÓRICO}

Recebido em 14/02/2020

Reapresentado em 22/03/2021

Aprovado em 08/04/202 